\title{
A research framework for the United Nations Decade of Healthy Ageing (2021-2030)
}

\author{
N. Keating ${ }^{1,2,3,4}$
}

Accepted: 22 December 2021 / Published online: 12 January 2022

(c) The Author(s) 2022

\begin{abstract}
The mission of UN Decade of Healthy Ageing (2020-2030) is to improve the lives of older people, their families and their communities. In this paper, we create a conceptual framework and research agenda for researchers to knowledge to address the Decade action items. The framework builds on the main components of healthy ageing: Environments (highlighting society and community) across life courses (of work and family) toward wellbeing (of individuals, family members and communities). Knowledge gaps are identified within each area as priority research actions. Within societal environments, interrogating beliefs about ageism and about familism are proposed as a way to illustrate how macro approaches to older people influence their experiences. We need to interrogate the extent to which communities are good places to grow old; and whether they have sufficient resources to be supportive to older residents. Further articulation of trajectories and turning points across the full span of work and of family life courses is proposed to better understand their diversities and the extent to which they lead to adequate financial and social resources in later life. Components of wellbeing are proposed to monitor improvement in the lives of older people, their families and communities. Researcher priorities can be informed by regional and national strategies reflecting Decade actions.
\end{abstract}

Keywords UN Decade of Healthy Ageing · Research framework · Environments $\cdot$ Life courses $\cdot$ Wellbeing

\section{Introduction}

In recent years, we have witnessed the growth of international debates about paradigms to frame action on population ageing. The debates have been populated with conversations about whether increasing proportions of older people comprise a demographic dividend (Fried and Rowe 2020); and how major global shocks such as pandemics,

Responsible Editor: M. Wahrendorf.

N. Keating

n.keating@swansea.ac.uk

1 Global Social Issues on Ageing (GSIA), International Association of Gerontology and Geriatrics, Buenos Aires, Argentina

2 Centre for Innovative Ageing, Swansea University, Swansea, UK

3 Research on Ageing, Policies and Practice (RAPP), University of Alberta, Edmonton, Canada

4 Optentia Research Unit, North-West University, Potchefstroom, South Africa mass migration and climate change affect states, their economics and their people (Carmody et al. 2021). They have raised fundamental questions of citizenship, exclusion and inequalities (Hallegatte and Rozenberg 2017).

United Nations (UN) agencies have been influential in shaping these global discourses. They have established a values agenda, with principles for people and their environments that set a moral compass for ageing. They have created a framework for healthy ageing that positions older people within these environments and articulates processes and outcomes.

The UN Decade of Healthy Ageing (2021-2030) brings together these agendas toward a better future for older people. Its plan of action signals shared accountability for "concerted, catalytic and collaborative action to improve the lives of older people, their families and the communities in which they live" (WHO 2020). Academics are held responsible along with governments, civil society, international agencies, professionals, the media and the private sector.

The purpose of this paper is to propose a roadmap for researchers across world regions to address this global challenge. The roadmap is framed specifically around the values, 
actions and outcomes embedded in the Decade Report and Action Plan and the knowledge that is needed to support them. It has a social science lens, informed by the main components of healthy ageing: environments across life courses toward wellbeing.

The paper is structured in four sections.

- Principles underlying the Decade of Healthy Ageing. Synopses are presented of the beliefs and values inherent in related UN documents that establish the moral compass for the Decade and its sense of urgency for action; and the ideas and approaches that form the conceptual compass to enhance healthy ageing.

- Priority areas for action described in the Decade of Healthy Ageing Plan of Action (WHO 2020). The four action areas have been endorsed by WHO member states and provide the broad guidelines against which countries can measure their progress.

- Framework and knowledge gaps. We articulate the conceptual approaches underpinning the Decade and priority areas for research to inform the Decade agenda.

- Toward 2030. In the final section of the paper, we bring together these components, discussing how the research agenda can contribute to the mission of "improving the lives of older people, their families and the communities in which they live".

\section{Principles underlying the UN Decade of Healthy Ageing}

For 75 years, the United Nations (UN) and its specialist agencies including the World Health Organization (WHO) have had as their mission fostering of global cooperation around economic, social and humanitarian challenges and human rights and freedoms. The Charter of the United Nations (UN no date) established its core purpose to maintain peace and security. It also set the foundations for a broad values agenda that includes universal respect for human rights, wellbeing and fundamental freedoms for all.

The UN Sustainable Development Goals (2015) reflect this history. With their mission to leave no one behind, they create a vision for inclusion of all people across all world regions. The SDGs focus on people and on environments, with broad aspirations to end poverty, protect the planet and improve the lives and prospects of people in all world regions. They were adopted by all UN Member States in 2015, forming part of the 2030 Agenda for Sustainable Development.

The values stance reflected in the SDG document provides a moral compass for moving forward. Presented as a universal agenda, the dignity of individuals and inclusion of all nations and people are emphasized. Core principles include human rights for all, gender equality, social justice and equitable access to resources. Both people and environments are central, although the interconnections among them are implicit. There are no goals specifically related to older persons. However, ensuring healthy lives and promoting wellbeing (SDG3) foreshadows healthy ageing initiatives. Older persons are mentioned in the context of reaching those who are furthest behind. The language used is that of vulnerable groups - older persons along with children, youth, persons with disabilities, people living with HIV, indigenous peoples, refugees, internally displaced persons and migrants (United Nations 2021).

The World Report on Ageing and Health (WHO 2015) focuses on ageing and older people in the global agenda to leave no one behind. Following the SDGs and initiatives focused specifically on older persons such as the International Year of Older Persons (1999), its approach also is rights-based although its language marks a shift from older people as vulnerable, to older people as excluded. The change is important, moving the discourse toward the ways in which environments often impede, but indeed could foster healthy ageing. Terms such as ageism and inequity are used throughout, illustrating this perspective and foreshadowing action items in the Decade of Healthy Ageing. A key contribution is its' focus on healthy ageing, providing a conceptual compass which is based on environments, in life courses and in wellbeing.

Environments are presented as an approach to understanding healthy ageing as a process of creating a good fit between individuals' intrinsic capacity (especially physical and mental health) and their environments (home, community and society). A core assumption is that those with chronic conditions can manage well if their environments are sufficiently supportive. It foreshadows actions calling for global changes to environments to foster inclusion and reduce inequalities.

The life course approach is invoked to underscore inequalities among older people; to argue that these arise from the cumulative impact of advantage and disadvantage across people's lives; and to label as inequities those differences that are unjust and must be addressed. The use of the term ageing reflects the assumption that lifelong processes shape late-life experiences.

Wellbeing is the third element of the approach to healthy ageing. Wellbeing is described as "the total universe of human life domains...that make up what can be called a "good life" (WHO 2015, p 244). A core assumption is that determination of a good life is grounded in the person's assessment of their ability to be and do what they most value. By virtue of it being positioned as an outcome of healthy ageing, wellbeing becomes central to determining the success of the Decade of Healthy Ageing actions. 


\section{Priority areas for action}

The UN Decade of Healthy Ageing brings together these agendas with a call to action. Its goal is to increase the significance of ageing, create urgency to act and generate change that transforms population ageing from a challenge to an opportunity (WHO 2020). The argument is compelling. The projected rapid rise in numbers of people age 60 and older from 1 billion in 2019 to 2.1 billion in 2050 underscores the significance of population ageing. Urgency is underscored by the fact that the majority of older people are in low- and middle-income countries. Many older persons have no access to the resources necessary for lives of meaning and dignity and confront multiple barriers that prevent their full participation in society. Core principles in the document are consistent with human rights and social justice themes.

The priority areas for action that form the basis of the report were established through extensive consultations with WHO member states, UN agencies and non-state actors. The action agenda is based on broad consensus of their importance and commitment to their implementation. The report highlights four key areas for action, each with directives to create policy, develop programs and build evidence. The Decade of Healthy Ageing was endorsed by the United Nations in December 2020.

Action 1. "Changing how people think, feel and act toward age and ageing" (WHO 2020, p 9). This action is described as challenging negative attitudes about age which are common in all societies. The argument is that reducing ageism is important given its pervasive impact on the way problems are seen, priorities are assessed, and solutions are determined. Ageism marginalizes older people, reducing appreciation of their social capital and limiting their access to services. There is a call for research on the social and economic implications of ageism and on the contributions of older people.

Action 2. "Ensure that communities foster the abilities of older people" (WHO 2020, p 9). This action is described as fostering physical, social and economic environments that are good places to "grow, live, work, play and age" (WHO 2020, p.9). The argument here is that age-friendly communities include older people; enable them to age where they want to be; and foster autonomy, dignity and wellbeing of older people and their family carers. There is acknowledgement that these actions must be undertaken with available human, material and financial resources. There are calls for building knowledge and understanding of age and ageing, developing tools to monitor progress in developing age-friendly environments and collecting geographically disaggregated data.
Action 3. "Deliver person-centered, integrated care and primary health services responsive to older people" (WHO 2020, p 12). The rationale for this action is that older people need access to essential health services that are non-discriminatory and do not create financial hardship. The goal is universal health coverage. A competent workforce, appropriate legislation and sustainable funding are essential. There are calls for research to develop measurement tools for healthy ageing, on evidence gaps in clinical data, and on changes in health systems.

Action 4. "Provide access to long-term care for older people who need it" (WHO 2020, p 14). The argument in support of this action area is that declines in intrinsic capacity can limit people's ability to care for themselves and participate in society. Access to long term care (LTC) helps people maintain their functional ability and live in dignity. The goal is that every country should have a system of long-term care that helps people maintain relationships and take part in activities that are meaningful for them. Reliance on families to provide LTC is seen as unsustainable and as inequitable notably for women. There are calls for comparative research on best LTC funding models in various resource settings and contexts, on cost effective interventions, and on the impact of long-term care on the wellbeing of recipients.

\section{Framing the research agenda}

The UN endorsement of the Decade places a global spotlight on ageing. It that provides a timely opportunity for researchers to articulate and support its mission by fostering theoretical conversations and empirical advancements that will encourage coordinated, global research efforts to understand the contexts, processes and outcomes of healthy ageing. The research agenda we propose is based on the core concepts of environments, life courses and wellbeing which reflect foundational principles of the approach to healthy ageing. It is grounded in the values and action items in the Decade agenda.

\section{Environments}

"Environments play a crucial role in promoting healthy ageing and ensuring no older person is left behind... Moreover, all domains of environments need to be assessed including support and relationships, attitudes, broader services, systems and policies" (WHO 2021, p 67).

From the SDGs through the Decade of Healthy Ageing and its action plan, environments have been presented as important in people's lives. The emphasis on environments in the World Report on Ageing and Health (WHO 2015) reflects a 
view that the contexts of ageing can influence wellbeing and exacerbate or reduce late-life inequalities. This perspective is grounded in human ecological assumptions that people have various capacities to act upon or adapt their environments and that person-environment fit occurs when environmental demands and opportunities are balanced with individual capabilities and resources (Bigonnesse and Chaudhury 2020). Two further assumptions illustrate its' values base: that responsibility for supporting those with limited agency must be shared; and that a goal is to identify and create evidence of those who are rendered invisible by contexts that exclude (Keating et al. 2021a, b).

Environments are social constructions, conceptualized as contexts or settings that are relevant to understanding a phenomenon of interest (Stephens et al. 2019). By naming specific environments, researchers declare research priorities and the scope of knowledge and knowledge gaps to be addressed within them. In this first part of the proposed research framework, we present two environments that are central to the phenomenon of healthy ageing: Society and Community. They are informed by the mission of the Decade and its main action areas. They reflect the assumption in social ecological models that environments are more or less distant from individuals (Keating and Phillips 2008). They are parsimonious, chosen to reflect key components of the values, beliefs, settings and relationships embedded in the Decade Action Plan and that shape experiences of ageing (Gelso 2006).

\section{Societal environment}

Societal environments are macro contexts that comprise beliefs and values of societies. It is within the societal environment that we find "values about age and ageing, about who is seen to be deserving of full citizenship and about how these cultural ways of knowing frame courses of action with a society" (Keating and Cheshire-Allen 2021). These value systems are important in influencing the goals set by governments, their policy actions and the ways in which individuals are affected and respond to them (Muers 2018). Two belief systems reflected in Decade Actions are ageism (Action 1) and familism (Action 4).

Ageism is "the complex, often negative construction of old age" (Ayalon and Tesch- Römer 2018, p 405) and a core element of the Decade action agenda. At the societal or structural level, ageism is the explicit or implicit bias against older persons that is embedded in societal norms and values and expressed in the policies, practices and actions of social institutions (Chang et al. 2020; Makore and AlMaiyah 2021). The call for a campaign to end ageism is an indication of beliefs that ageism truncates the ability of ageing individuals to be fully included in their societies and is a hidden source of inequity (Kilaru and Gee 2020). Research and conceptual development on social exclusion has begun to reveal the ways in which societal beliefs and actions can exclude older people from full citizenship in areas such as services, amenities, mobility, social relations, material and financial resources and civic participation (Walsh et al. 2017).

The research backdrop to reducing societal ageism lies in understanding its development, persistence and diversity across societies (Marques et al. 2020). We have relatively good knowledge of these domains for individual ageism (see for example, WHO Global Report on Ageism 2021). Less is known about these at the structural level-an important knowledge base if we are to understand the likelihood that governments might pass human rights legislation that addresses age discrimination or modify existing instruments that permit it (WHO 2021 January).

Two areas that would benefit from further conceptual development and empirical examination at societal/institutional levels are positive ageism and implicit ageism. Positive ageism positions older people as worthy but needing nurturing and protection, making them subordinate to others who know best (Vervaecke and Meisner 2021). The negative impact of such beliefs was evident during the early phases of the Covid-19 pandemic. Many countries placed greater restrictions on older persons, accompanied by public communication that was patronizing and homogenizing, depicting all older adults as 'vulnerable' members of society (Fraser et al. 2020).

Implicit ageism is more difficult to identify and thus challenge. It includes what might be called averted ageism, arising from society's gaze being on what are seen as more pressing issues such as the enablement of youth (Roux and Viljeon 2018). As scarcity of resources increases, especially in the face of increased numbers of older people, tensions over resource allocation lead to higher rates of ageism (Goldani 2010; Marques et al. 2020). Further, articulating societal approaches to ageism will provide a solid basis for tracking progress toward reducing its impact across countries and settings.

We include familism as the second set of societal beliefs and values comprising the main constructs in the societal environment. Familism is not named specifically in the Decade Action Plan, though its principles are alluded to in such statements as how holding families responsible for care of their older members is both unsustainable and inequitable. The pervasiveness of familism and its' often-implicit assumptions make it both important and challenging to deconstruct. Like ageism, familism shapes lives.

Familism is beliefs about the centrality and responsibility of families for their individual members (Mucchi-Faina et al. 2010). At the societal level, it is reflected in the extent to which the state views families as responsible for the welfare of their members. Family responsibility may be entrenched 
through the absence of public policy support (familism by default); or active enforcement via policies such as family responsibility legislation, income transfers or workplace leaves (supported familism) (Ting and Woo 2009; Saraceno 2016). In periods of economic recession, there is a retreat to familism among welfare states (León and Pavolini 2014).

Outside of the welfare states in the global north, familism is often expressed as a core societal belief. In Latin America, familism has been described as an important cultural construct that prioritizes personal obligation to family needs (Hernandez and Bamaca-Colbert 2016). Button et al. (2018) speak of a widespread belief in kinship obligations in post-apartheid South Africa, with large numbers of people dependent on kin for either financial support or personal care. In turn, the so-called Black Tax (Webb 2021) illustrates the expected reciprocal support from younger people to family members.

The idea that families should be solely responsible for the care of their members has been described as "simultaneously commonsensical and strange" (Poletta 2018, p 230). Challenges to ideas of familism as benevolent have come primarily from researchers studying family care. There is considerable evidence that taken for granted assumptions about family care work as "natural and preferred" (Kemp 2021, p 145-146) come at high cost to carers' labour force engagement (Casado- Marín et al. 2011), physical and mental health (Bauer and Sousa-Poza 2015) and family relationships (Broese van Groenou and De Boer 2016; Keating and Eales 2017). There has been less examination of the impact of familism on older adults or on families in the global south.

Levels of familism and beliefs about their positive impact on older persons and their families warrant further consideration. The commonsensical aspect of familism seems well-engrained, though we believe it has been insufficiently examined across geographic settings and policy contexts. Lack of action to address familism may be akin to familism by default (Kodate and Tinomen 2017), in which families are presumed to be in the best position to care for older members regardless of their ability, availability or suitability — a belief that it challenged in the Decade action on long term care.

\section{Community Environment}

Communities are most often described as meso contexts of physical and social settings in which people live their lives (Wahl and Oswald 2016). They include built and natural features, services and infrastructure and points of connection among residents (Andrews et al. 2013) and are viewed as having potential to provide a sense of place and of belonging (Obadia 2015; Wiles et al. 2017). Communities are a central part of the discussion of environments of healthy ageing (Action 2). In the language of the Decade Action Plan, there is an expectation that communities will be environments that are good places to "grow, live, work, play and age" (WHO 2020 p 9).

Environmental gerontologists have been instrumental in providing evidence of the positive role of built environments and belongingness in the wellbeing of older persons (Ahn et al. 2020; Moyano-Díaz et al. 2021). Yet research evidence by no means presents communities as universally good places to grow old. Ageing in place can embed disadvantage for people in settings with poor infrastructure, precarious housing, fear and mistrust (Finlay et al. 2020; Bates et al. 2019). Researchers and theorists seeking to understand social exclusion of older persons have articulated domains and processes through which older people may be denied full participation in their communities, regardless of level of community resources (Walsh et al. 2021).

A research issue that emerges from these findings is the extent to which communities differ in their ability to be supportive to a diversity of older residents. Community inequalities are particularly relevant to the Decade action item on community supportiveness given the growth of age-friendly approaches that establish domains within which communities are encouraged to act to meet the needs of their ageing populations (Sis et al 2020). Yet there is evidence that people with the greatest need for age-friendly interventions do not always reside in places with the capacity to implement them (Golant 2014). Researchers have articulated a need to better understand the ability of community structures and systems to address age-friendly principles (Rémillard-Boilard et al 2021; Winterton 2016).

A next step in understanding communities as contexts for healthy ageing is to investigate the extent to which communities themselves may be characterized by vulnerability (Skinner et al. 2016). Researchers have argued, for example, that rural communities may be poorly equipped to address older peoples' needs given population decline, remoteness, limited fiscal resources and reliance on volunteers (McCrillis et al. 2021). Placing communities within macro contexts such as pandemics, climate change and political instability will also add considerably to our understanding of drivers of community capacity.

\section{Life courses}

"We frame ageing within the life course" (Beard 2018, p A1).

In his reflection on the work of the WHO in formulating its approach to ageing, Beard underscored its' emphasis on events and transitions that shape later life. The term Healthy Ageing was chosen to reflect the belief that if more people are to experience a good old age, we must incorporate processes across time as lives unfold. Researchers agree that if we want to fully understand later life, we must situate 
it within the socially constructed nature of the life course (Holman and Walker 2020).

A core assumption of life-course theory is that life pathways create the structure and rhythm of individual lives (Dannefer and Kelley-Moore 2009). Life course theorists have long been engaged in specifying these pathways, arguing that there is no singular life course, but several domains, each with transitions that punctuate it (Elder 1985; Elder and George 2016). In this second component of the research framework for a Decade of Healthy Ageing, we present life courses that we believe are especially relevant to understanding healthy ageing.

The Decade Report and Action Plan is grounded in pathways of intrinsic capacity. In its report on life courses of health, the Pan American Health Organization (2021) describes pathways of physical and mental health that diverge across the life course, leading to differences in risk of disease and healthy life expectancy. While the overall shape of health trajectories is hypothesized, turning points or transitions are not articulated. Nonetheless, the authors argue that the shift from health as a status to health as a process broadens the epidemiological model of health through its recognition of "biological, psychological, physical, social, and environmental influences that operate from conception to death" (PAHO 2021, p 23). Further specification of health trajectories is important in informing the Decade Action item of delivering essential health services (Action 3).

Conceptualizing health as a life course process, creates an opportunity to explicitly incorporate other life course domains. As with environments, we have yet to fully explore which life courses are most critical to healthy ageing. While the possibility for differentiated life course trajectories to influence later life outcomes is clear, the extent to which this happens as people's lives unfold has not been sufficiently conceptualized (Walsh et al. 2020, p 2324). Further articulation and exploration of these pathways will illustrate cumulative advantage or disadvantage that are the precursors to late life inequalities.

We propose two additional life course domains to frame ageing within the life course: Work and Family. Each is important in shaping the lives of adults as they age. Each has transitions and trajectories that underscore the relevance of changes across time and their contributions to diversity in later life outcomes (Alwin 2013). In keeping with the focus in the Decade Action Plan, gaps in knowledge of transitions in the second half of life are emphasized.

\section{Work life courses}

Work trajectories have been conceptualized as a series of labor market states whose components include transitions between jobs, movement in and out of jobs and the overall timing of these shifts within individuals' careers (Liukkonen et al. 2009; McDonough et al. 2017). There is a widely held belief that employment life courses have become more complex, more unstable and less predictable (Van Winkle and Fasang 2017), although this assumption has yet to be tested across the entire employment life course.

There has been recent interest in later life labor force engagement and exit that has illustrated difficulties for older workers in transitions such as re-entry into the labor force after a period of absence (Visser et al. 2018); and the extent to which types of retirement have differential impact on wellbeing (Radó and Boissonneault 2020). Other research has provided insights into transitions and processes across other elements of the employment life course. Scholars have articulated the start and end points of employment pathways through examination of how national policies and programmes structure age of (first) entry into and (final) exit from the labour force (Larsson and Stattin 2015; Clark et al. 2017). Diversity among work pathways has been explored through micro-transitions between employment to unemployment (Hägglund and Bächmann 2017), full time and part time work (Van Winkle and Fasang 2017) and sequential precarious employment (Raymo et al. 2011). Analyses across life courses of work with specific characteristics such as being precarious (Ní Léime and Street 2019) or physically demanding (Nicholas et al. 2020) have illustrated how work characteristics can have a cumulative effect on later life outcomes of poverty and illness/disability.

The next step is to map transitions and trajectories across the full span of a work career. Ní Léime and Street (2019) argue that there are two components needing further development. The first is the span of a working life. Research under the rubric of extending working lives (Lain et al. 2020) has illustrated advantages and disadvantages of lengthening the later part of the employment life course. There has been little research on how late-career extensions influence the overall length of working lives. One illustrative report raises a cautionary note about assuming benefits arise from long labor force careers. The authors found that across countries in Europe, those with the lowest expected years of labor market engagement have the highest life expectancy (Hytti and Valaste 2009) suggesting that shorter working lives are afforded to those who are most privileged.

The second component is the demands made on that working life. Features of work life courses may comprise a set of conditions that render work lives particularly challenging. How does long term engagement in precarious work with little security or benefits and low pay, result in lives infused with uncertainty and instability (Campbell and Price 2016)? In what ways does lifetime occupational engagement in physically and cognitively demanding jobs limit work capacity later in life (Nicholas et al. 2020)? Which workers are most advantaged by job flexibility and at what points in their employment life course (Kossek and Lautsch 2018)? 
These examples illustrate evidence gaps in how these and other demands shape how life courses of work will unfold.

There is much scope for further conceptual and empirical work to address knowledge gaps in life courses of work. We highlight one that we believe is relevant to the Decade of Healthy Ageing principle of reducing inequalities. It is to adopt definitions of work that incorporate the majority of workers in the global population who work in the informal sector (Bonnet et al. 2019; Mitra 2015). Informality encompasses a wide range of jobs and economic activities without work-based social protection where workers are usually poorer and more vulnerable than workers in formal employment (Bonnet et al. 2019). Importantly, such definitions could provide a context for examining life courses that might include precarity in both formal and informal employment (Burchielli et al. 2014; Siegmann and Schiphorst 2016). Such examinations could provide the basis for understanding how over time, precarious work might be associated with precarity as a general condition of later life (Campbell and Price 2016).

\section{Family life courses}

Life course perspectives on families have long been a central feature of family scholarship. Structural approaches featuring changes in family composition are foundational to much of this theorizing. An early example posited a succession of stages through which families pass during their life span. Marriage marked family formation; children were its main transitions; death of a spouse the final exit (Glick 1977; Rogers 1964). This so-called standard American family (SNAF) was challenged as an ideological code that reproduced itself in beliefs about ideal and deficit families (Marotz-Baden et al. 1979; Smith 1993). While family life course scholarship has developed considerably since this early thinking, it is worth noting that a major theme in the current concern about wellbeing of older people is the availability of children to provide support.

Contemporary family life course scholarship also draws on structural transitions, but with an assumption of diversity of family forms. Scholars have shown increased variation in family transitions resulting from policy changes such as the liberalization of laws regulating marriage and divorce (Jowett 2017) and changes in social mores such as those related to cohabitation (Stoilova et al. 2017) and fertility (Engin et al. 2020). For the most part, each transition has been studied separately, providing data on the likelihood of being childless (Kreyenfeld and Konietzka 2017), evermarried (Keenan et al 2017), divorced (Couch et al 2020) or widowed (Schmitz 2021) during their lives. We know less about how patterns of these family states and transitions combine to create trajectories that may differ in their potential for late-life family connections.
Researchers have begun to address this knowledge gap, illustrating the usefulness of trajectories in documenting the extent to which families have become more diverse, uncertain or fragile. For example, in a study of patterns of "relationship turnover" among people age 15-45 in Europe, Perelli-Harris and Lyons-Amos (2015) found eight distinct trajectories of cohabitation, marriage and union dissolution. A similar study of transitions in "family formation" including being single, cohabiting, married and presence of children found five dominant patterns among people age 15-50 (Van Winkle 2018). Together these studies contribute to an understanding of diversity in segments of family life courses.

Documenting family transitions in the second half of life is new conceptual territory. It requires us to identify and incorporate transitions in partnership status and in generational membership, determining which are critical to understanding how family lives evolve. It places us in a position to interrogate the key family transitions across the entire life course and test their validity across countries and regions. In combination, this conceptual and empirical work would allow for a more systematic approach to understanding diversity in family trajectories and how these may lead to different family experiences for older persons.

While structures set the boundaries around family membership, family members live in relationship (Carr and Utz 2020; Landes and Settersten 2019). Family lives are linked through their interdependence over time through the transfer of material resources (Gilligan et al. 2018), though production in family enterprises (Rondi et al. 2019) and through care for grandchildren and for older family members (Hoang et al. 2019).

These linkages can be sources of ongoing support, although here too we see evidence of heterogeneity. Diverse family life courses have produced forms of relatedness (Silverstein and Giarrusso 2010) that can lead to late life exclusion (Gilligan et al. 2018). There is evidence, for example, that across family life courses in which couples have divorced, older men are less likely than women to receive material support from children (Maes et al. 2020). Siblings estranged over tensions in parent care may be unprepared to support each other in later life (Jensen et al. 2020; Keating et al. 2019). Older adults without children or partners have lower levels of conflict in their family networks, perhaps because their absence allows for more elective involvement in their families and more choice of supportive relationships (Giardin et al. 2018; Widmer et al. 2018).

Family life courses provide researchers an opportunity to address the theme in the Decade Action Plan of the place of families in the lives of older persons. The family life course assumption of family diversity, raises the question of the extent to which different family trajectories lead to inclusion or exclusion from supportive family relationships in later life. A next step is to complete the work of developing 
typologies of family life courses and validate them across world regions. In concert with this mapping of life courses of families, more attention needs to be paid to how family connections and relationships also evolve and the extent to which lives that are linked enhance quality of life for people in those relationships (Bengtson and Allen 2009).

\section{Wellbeing}

"The total universe of human life domains...that make up what can be called a "good life" (WHO 2015, p 244).

From the Sustainable Development Goals through actions to enhance healthy ageing in the Decade Action Plan, wellbeing has been central to the narrative of desired outcomes. In this final section of the research framework, we return to the challenge presented in the introduction to the paper - that if wellbeing of older people, their families and communities are the outcome of healthy ageing, we need articulate approaches to monitoring our progress.

There is a large body of research on the wellbeing of older adults. To a great extent it has been grounded in quality of life (Fernández-Ballesteros 2011; Tseng et al. 2018). The World Health Organization definition is widely used: "an individual's perception of their position in life in the context of the culture and value systems in which they live, and in relation to their goals, expectations, standards and concerns" (The WHOQOL Group 1998). Others have argued that objective factors including health and financial resources as well as social relations should be included (González et al. 2021; Karimi and Brazier 2016).

Together these perspectives comprise ideas of 'being well' reflected in people's evaluations of whether their situation allows them to live the life they most value (McGregor 2007); and of 'doing well' through having sufficient material and social resources (Sen 1999; Tronto 2017). They are consistent with the environmental gerontology perspective of ageing as a process of calibrating person-environment fit over time (Wahl and Oswald 2016). They can provide a platform to further articulate healthy ageing as people's ability to function well in the contexts in which they live (Michel et al. 2021).

There are longstanding debates about the ideal conceptualization of wellbeing (Gillett-Swan and Sargeant 2015; Mikton C, personal communication). Engaging in these debates goes beyond the scope of this paper which is to inform build knowledge about wellbeing to inform the UN Decade. These are to determine which groups will be the focus and to articulate the "being well" and "doing well" domains for each.

Two groups have been central to our understanding of outcomes of healthy ageing: older persons and families. The priority for conceptualizing wellbeing of older persons is to understand and support processes of healthy ageing that enhance their ability to be and do what they most value. Families are featured as caregivers to older persons with chronic health problems whose wellbeing is important to sustainability of care.

Details of material, relational and subjective domains of older persons and family members have been the subject of recent research. Based on evidence of resources that underpin people's ability to live well, health, income and housing seem reasonably placed as core components of their material wellbeing (Bates et al. 2019; Gildner et al. 2019; Ng et al. 2017). Core elements of relational wellbeing include family members and friends (Vos et al. 2020), although we have much to learn about variation in the extent to which these relationships are supportive.

Incorporating knowledge of diversity in areas such as ambiguous or exploitive family relations or decreased friend networks in the face of illness and death are examples. A systematic review of wellbeing of family caregivers found that material resources (including labour force participation and care-related out of pocket expenses); and relational resources (including with the cared-for person, other family members, friends and co-workers) are most important (Keating et al. 2021a, b). There is merit in further empirical examination of what are the core resources and relationships in their lives.

The scope of subjective wellbeing needs additional critical examination. Many measures are situation specific such as health-related quality of life for older persons (VelardeJurado and Avila-Figueroa 2002) and caregiver burden for family caregivers (van Exel et al. 2004). If the ability to be and do what you most value is the outcome of interest, then a broader view of subjective wellbeing in life goals warrants consideration.

Which other family members of older adults might be included in this wellbeing theorizing? Priority could be placed on marginalized families such as migrants who relocate to escape political or economic instability, leaving behind older relatives too ill to travel (C. Licopantis, personal communication). How do we calibrate wellbeing of such family members with impoverished material situations, severed relationships and who may be suffering from exposure to repeated incidents of moral distress (Molendijk 2018)? More generally, what are minimally acceptable levels of wellbeing across the groups of individuals described here? The social justice component of this theorizing requires us to be unequivocal about what resources are necessary and how they will be distributed (Nussbaum 2002).

Community wellbeing is a key element of the Decade mission. However, despite the Decade Action calling on communities to foster the abilities of older people, there has been little exploration of the capacity of communities to do 
this, Wellbeing could provide a way to evaluate the sufficiency of community material resources (e.g., infrastructure and local economy) and relationships (e.g., sense of coherence and participation) (DeVerteuil et al. 2020; Ryser et al. 2021) as well as community narratives (e.g., as flourishing or left behind) (Li and Zehr 2020; Wiseman and Brasher 2008). Mapping diversities across these wellbeing domains could help us better understand the extent to which older people with the greatest need for age-friendly interventions do not always reside in places with the capacity to implement them (Cueva et al 2021; Winterton 2016).

\section{Toward 2030}

The research framework presented here provides a structure for researchers who wish to target their research efforts to inform the UN Decade of Healthy Ageing. It builds on the main components of healthy ageing: Environments (highlighting society and community) across life courses (of health, work and family) toward wellbeing (of individuals, family members and communities).

Across world regions, countries are developing responses to the Decade Action Plan. These documents express commitment to the plan and signal priority areas where knowledge creation might be particularly timely in informing policy decisions to address Decade goals. For example, in its National Strategic Plan on Ageing, Indonesia stresses the importance of all action items (The Ministry of Justice and Human Rights the Republic of Indonesia 2021). A recent analysis of Indonesia's ageing policies suggests priority areas related to Action item 1, specifically how ageism excludes older persons from late life income security; and Action items 1 and 4, how familist perspectives place care of older people in the private sphere (Lestari et al. 2021). Chile also endorses Decade action items, presenting its national plan as an opportunity to create public policies from a social healthcare and rights perspective (Gobierno de Chile 2021). The focus of the first part of its Decade strategy responds to action items 3 and 4: improving health care and long-term care for older persons (Ministerio de Salud 2021).

Countries in Africa have taken a different approach to articulating priorities in their region to address the Decade Action Plan. A draft set of priorities written by academics in the region and circulated widely for feedback from civil society organizations, is now being considered for adoption by the AU (African Union). The main priorities are consistent with understanding connections between life courses and wellbeing. Its core argument is that strategic investments across the life course will enhance capacities and wellbeing in older age and benefit both older and younger people. Eliminating ageism and ensuring communities and families have adequate capacities and resources are priorities linked to Action items 1, 2 and 4 (J. Hoffman, personal communication).

Other national and regional strategies may also provide indications of areas in which countries are prepared to act. For example, Canada's Dementia Strategy (Public Health Agency of Canada 2021) calls for evidence of successful interventions (relevant to Action item 4) and of contributions of build and social environments to wellbeing of persons with dementia (Action item 2). The European Commission and WHO Regional Office for Europe's Age-friendly environments in Europe (no date) emphasizes the importance of local and regional authorities making strong commitment to supporting older residents (Action item 2). Age Platform Europe (no date) is a source of decade research priorities from the perspective of older people.

While the UN Decade has global research, evidence to support understanding of environments, life courses and wellbeing will be grounded within countries and regions. Taking global diversity and global voices seriously requires questioning assumptions around ideal life course pathways (Mokomane 2021); including how intersectionalities of gender, race and social class may contribute to widening inequalities across life courses (Folbre 2020); and changes in the fit between persons and their environments over time might comprise tipping points in later life precarity (Keating et al. 2013; Urbaniak and Walsh 2019). We must be mindful of the moral compass set out in the Sustainable Development Goals. It requires us to see inequalities and to foster inclusion. As researchers what we choose to study, the language we use and the data we collect will help determine the extent to which the lives of older persons are improved across the life domains articulated in this framework.

Acknowledgements This research was supported by the generous contributions of ideas, conceptual debates and research findings from colleagues in all world regions who are acknowledged here. Conclusions are the authors own. Liat Ayalon; John Beard; Marjolein Broese van Groenou; Tine Buffel; Carmen-Lucia Curcio; Denise EldemireShearer; Jaco Hoffman; Shereen Hussein; Majella Kilkey; Kelly Hall; Kai Leichsenring; Made Diah Lestari; Richard Lewanczuk; Christina Licopantis; Magdolna Lorinc; Christopher Mikton; Veronica Montes de Oca; Vânia de la Fuente Núñez; Alana Officer; Judith Phillips; Anne Margriet Pot; Ian Rothmann; Thomas Scharf; Elisabeth ShroederButterfill; Alexandre Sidorenko; Obert Tawodzera; Clemens TeschRoemer; Sandra Torres; Kieran Walsh; Douladel Willie-Tyndale.

\section{Declarations}

Conflict of interest No conflict of interest or competing interest.

Open Access This article is licensed under a Creative Commons Attribution 4.0 International License, which permits use, sharing, adaptation, distribution and reproduction in any medium or format, as long as you give appropriate credit to the original author(s) and the source, provide a link to the Creative Commons licence, and indicate if changes were made. The images or other third party material in this article are included in the article's Creative Commons licence, unless indicated 
otherwise in a credit line to the material. If material is not included in the article's Creative Commons licence and your intended use is not permitted by statutory regulation or exceeds the permitted use, you will need to obtain permission directly from the copyright holder. To view a copy of this licence, visit http://creativecommons.org/licenses/by/4.0/.

\section{References}

Ahn M, Kang J, Kwon HJ (2020) The concept of aging in place as intention. Gerontologist 60(1):50-59. https://doi.org/10.1093/ geront/gny 167

Alwin DF (2013) Life course, life cycle, life history, life span and life stage. In: Runehov A, Oviedo L (eds) Encyclopedia of sciences and religions. Springer, Dordrecht, p 1167

Andrews G, Evans J, Wiles J (2013) Re-spacing and re-placing gerontology: relationality and affect. Ag Soc 33:1339-1373. https:// doi.org/10.1017/S0144686X12000621

Ayalon L, Tesch-Römer C (eds) (2018) Contemporary perspectives on ageism. Springer Nature, Geneva. https://doi.org/10.1007/ 978-3-319-73820-8

Bates L, Wiles J, Kearns R, Coleman T (2019) Precariously placed: home, housing and wellbeing for older renters. Health Place 58:102152. https://doi.org/10.1016/j.healthplace.2019.102152

Bauer J, Sousa-Poza A (2015) Impacts of informal caregiving on caregiver employment, health, and family. Popul Ag 8:113-145. https://doi.org/10.1007/s12062-015-9116-0

Beard J (2018) Feature interview with Dr. John Beard. J Econ Ag 12:A1-A5

Bengtson VL, Allen KR (2009) The life course perspective applied to families over time. In: Boss P, Doherty WJ, LaRossa R, Schumm WR, Steinmetz SK (eds) Sourcebook of family theories and methods. Springer, Boston MA, pp 469-504

Bigonnesse C, Chaudhury H (2020) The landscape of "aging in place" in gerontology literature: emergence, theoretical perspectives, and influencing factors. J Ag Environ 34(3):233-251. https://doi. org/10.1080/02763893.2019.1638875

Bonnet F, Vanek J, Chen M (2019) Women and men in the informal economy - a statistical brief. Manchester, UK: Women in Informal Employment: Globalizing and Organizing (WIEGO). https:// www.ilo.org/wcmsp5/groups/public/---ed_protect/---protrav/--travail/documents/publication/wcms_711798.pdf Accessed 25 June 2021.

Broese van Groenou MI, De Boer A (2016) Providing informal care in a changing society. Eur J Ag 13:271-279. https://doi.org/10. 1007/s10433-016-0370-7

Burchielli R, Delaney A, Goren N (2014) Garment homework in Argentina: drawing together the threads of informal and precarious work. Econ Labour Relat Rev 25(1):63-80

Button K, Moore E, Seekings J (2018) South Africa's hybrid care regime: the changing and contested roles of individuals, families and the state after apartheid. Curr Sociol Monogr 66(4):602-616

Campbell I, Price R (2016) Precarious work and precarious workers: towards an improved conceptualization. Econ Labour Relat Rev 27(3):314-332

Carmody P, McCann G, Colleran C, O’Halloran C (eds) (2021) Covid19 in the Global South: impacts and responses. Bristol University Press, Bristol

Carr D, Utz RL (2020) Families in later life: a decade in review. J Marriage Fam 82:346-363. https://doi.org/10.1111/jomf.12609

Casado-Marín D, García-Gómez P, López-Nicolás Á (2011) Informal care and labour force participation among middle-aged women in Spain. Series 2:1-29. https://doi.org/10.1007/s13209-009-0008-5

Chang ES, Kannoth S, Levy S, Wang SY, Lee JE, Levy BR (2020) Global reach of ageism on older persons' health: a systematic review. PLoS ONE 15(1):1-24. https://doi.org/10.1371/journal. pone. 0220857

Clark C, Smuk M, Lain D, Stansfeld SA, Carr E, Head J, Vickerstaff S (2017) Impact of childhood and adulthood psychological health on labour force participation and exit in later life. Psychol Med 47(9):1597-1608. https://doi.org/10.1017/s0033291717000010

Couch KA, Tamborini CR, Reznik GL, Phillips JWR (2020) Chapter eight. divorce, women's earnings, and retirement over the life course. In: Couch KA, Daly MC, Zissimopoulos JM (eds) Lifecycle events and their consequences. Stanford University Press, Redwood City, pp 133-157

Cueva K, Rink E, Lavoie JG et al (2021) Diving below the surface: a framework for arctic health research to support thriving communities. Scand J Public Health. https://doi.org/10.1177/14034 948211007694

Dannefer D, Kelley-Moore JA (2009) Theorizing the life course: new twists in the paths. In: Bengston V, Silverstein M, Putney N, Gans D (eds) Handbook of theories of aging, 2nd edn. Springer, New York, pp 389-411

DeVerteuil G, Kiener J, Mizuuchi T (2020) The service hub as bypassed social infrastructure: evidence from inner-city Osaka. Urban Geogr. https://doi.org/10.1080/02723638.2020.1826751

Elder GH (1985) Perspectives on the life course. In: Elder GH (ed) Life course dynamics: trajectories and transitions, 1968-1980. Cornell University Press, Ithaca NY, pp 23-49

Elder GH, George LK (2016) Age, cohorts, and the life course. In: Shanahan MJ, Mortimer J, Kirkpatrick Johnson M (eds) Handbook of the life course, vol II. Handbooks of sociology and social research. Springer, Switzerland, pp 59-85

Engin C, Hürman H, Harvey K (2020) Marriage and family in Turkey: trends and attitudes. In: Farris D, Bourque A (eds) International handbook on the demography of marriage and the family, international handbooks of population, vol 7. Springer, Switzerland, pp 105-119

European Commission and WHO Regional Office for Europe (no date). Age-friendly environments in Europe (AFEE). https:// www.euro.who.int/en/health-topics/Life-stages/healthy-ageing/ activities/age-friendly-environments-in-europe-afee Accessed 27 November 2021

Fernández-Ballesteros R (2011) Quality of life in old age: problematic issues. Appl Res Qual Life 6:21-40. https://doi.org/10.1007/ s11482-010-9110-x

Finlay J, Gaugler J, Kane R (2020) Ageing in the margins: expectations of and struggles for 'a good place to grow old' among lowincome older Minnesotans. Ag Soc 40(4):759-783. https://doi. org/10.1017/S0144686X1800123X

Folbre N (2020) Manifold exploitations: toward an intersectional political economy. Rev Soc Econ 78(4):451-472. https://doi.org/10. $1080 / 00346764.2020 .1798493$

Fraser S et al (2020) Ageism and COVID-19: What does our society's response say about us? Age Ag 49:692-695. https://doi.org/10. 1093/ageing/afaa097

Fried L, Rowe J (2020) Health in aging - past, present, and future. N Engl J Med 383:1293-1296. https://doi.org/10.1056/NEJMp 2016814

Gelso CJ (2006) Applying theories to research: the interplay of theory and research in science. In: Leong FT, Austin JT (eds) The psychology research handbook: a guide for graduate students and research assistants. Sage, Thousand Oaks CA, pp 455-464

Gildner TE et al (2019) Perceived income adequacy and well-being among older adults in six low- and middle-income countries. $\mathbf{J}$ Gerontol: Ser B 74(3):516-525. https://doi.org/10.1093/geronb/ gbw145

Gillett-Swan J, Sargeant J (2015) Wellbeing as a process of accrual: beyond subjectivity and beyond the moment. Soc Indic Res 121:135-148. https://doi.org/10.1007/s11205-014-0634-6 
Gilligan M, Karraker A, Jasper A (2018) Linked lives and cumulative inequality: a multigenerational family life course framework. J Fam Theory Rev 10:111-125. https://doi.org/10.1111/jftr. 12244

Girardin M, Widmer ED, Connidis IA, Castrén AM, Gouveia R, Masotti B (2018) Ambivalence in later-life family networks: beyond intergenerational dyads. J Marriage Fam 80:768-784. https://doi.org/10.1111/jomf.12469

Glick P (1977) Updating the life cycle of the family. J Marriage Fam 39(1):5-13. https://doi.org/10.2307/351058

Gobierno de Chile (2021). Chile leads launch of Decade of Healthy Ageing 2021-2030, which seeks to improve conditions for older people. https://www.gob.cl/en/news/chile-leads-launchdecade-healthy-ageing-2021-2030-which-seeks-improve-condi tions-older-people/ Accessed 25 November 2021

Golant S (2014) Age-friendly communities: are we expecting too much? Institute for Research on Public Policy (IRPP). https:// on-irpp.org/37HR $4 \mathrm{cr}$

Goldani AM (2010) "Ageism" in Brazil: What is it? Who does it? what to do with it? Revista Brasileira De Estudos De População 27(2):385-405. https://doi.org/10.1590/S0102-30982 010000200009

González P, Dussaillant F, Calvo E (2021) Social and individual subjective wellbeing and capabilities in Chile. Front Psychol 11:4080. https://doi.org/10.3389/fpsyg.2020.628785

Hägglund AE, Bächmann AC (2017) Fast lane or down the drain? Does the occupation held prior to unemployment shape the transition back to work? Res Soc Stratif Mobil 49:32-46. https://doi.org/10.1016/j.rssm.2017.03.005

Hallegatte S, Rozenberg J (2017) Climate change through a poverty lens. Nature Clim Change 7:250-256. https://doi.org/10.1038/ nclimate 3253

Hernandez M, Bamaca-Colbert M (2016) A behavioral process model of familism. J Fam Theory Rev 8(December):463-483. https://doi.org/10.1111/jftr.12166

Hoang NPT, Haslam D, Sanders MR (2019) Coparenting conflict and cooperation between parents and grandparents in Vietnamese families: the role of grandparent psychological control and parent-grandparent communication. Fam Process 59(6):11611174. https://doi.org/10.1111/famp.12496

Holman D, Walker A (2020) Understanding unequal ageing: towards a synthesis of intersectionality and life course analyses. Eur J Ag 18:239-255. https://doi.org/10.1007/s10433-020-00582-7

Hytti H, Valaste M (2009) The average length of working life in the European Union. The Social Insurance Institution, Finland (Kela) Research Department, online working papers 1. https://helda.helsinki.fi/bitstream/handle/10250/8369/The? sequence $=5$

Jensen A, Nielson M, Yorgason J (2020) The longest-lasting relationship: patterns of contact and well-being among mid- to later-life siblings. J Gerontol B Psychol Sci Soc Sci 75(10):2240-2249. https://doi.org/10.1093/geronb/gbz083

Jowett A (2017) 'One can hardly call them homophobic': denials of antigay prejudice within the same-sex marriage debate. Discourse Soc 28(3):281-295

Karimi M, Brazier J (2016) Health, health-related quality of life, and quality of life: what is the difference? Pharmacoeconomics 34:645-649. https://doi.org/10.1007/s40273-016-0389-9

Keating N, Eales J (2017) Social consequences of family care to adults: a scoping review. Int J Care Caring 1(2):153-173. https://doi.org/ 10.1332/239788217X14937990731749

Keating N, Cheshire-Allen M (2021) Policy to reduce late-life social exclusion: from aspirations to action. In: Walsh K, Scharf T, Van Regenmortel S, Wanka A (eds) Social exclusion in ageing societies: interdisciplinary and policy perspectives. Springer, Switzerland, pp 353-357
Keating N, Phillips JE (2008) A critical human ecology perspective on rural ageing. In: Keating N (ed) Rural ageing: a good place to grow old? Policy Press, Bristol UK, pp 1-10

Keating N, Eales J, Phillips J (2013) Age-friendly rural communities: conceptualizing 'best-fit.' Can J Ag 32(4):319-332. https://doi. org/10.1017/s0714980813000408

Keating N, Eales J, Funk L, Fast J, Min J (2019) Life course trajectories of family care. Int J Care Caring 3(2):147-163. https://doi.org/ 10.1332/239788219X15473079319309

Keating N, McGregor JA, Yeandle S (2021b) Sustainable care: theorising the wellbeing of caregivers to older adults. Int J Care Caring. https://doi.org/10.1332/239788221X16208334299524

Keating N, Eales J, Phillips J, Ayalon L, Lazaro M, de Montes Oca V, Rea P, Tyagi P (2021) Global contexts of rural ageing: informing critical human ecology theory. In: Skinner M, Winterton R, Walsh K (eds) Rural gerontology: towards critical perspectives on rural ageing, chapter 5. Routledge, London

Keenan K, Ploubidis GB, Silverwood RJ, Grundy E (2017) Life-course partnership history and midlife health behaviours in a populationbased birth cohort. J Epidemiol Commun Health 71:232-238. https://doi.org/10.1136/jech-2015-207051

Kemp C (2021) \#MoreThanAVisitor: families as "essential" care partners during COVID-19. Gerontologist 61(2):145-151. https:// doi.org/10.1093/geront/gnaa161

Kilaru AS, Gee RE (2020) Structural ageism and the health of older adults. JAMA Health Forum 1(10):e201249. https://doi.org/10. 1001/jamahealthforum.2020.1249

Kreyenfeld M, Konietzka D (eds) (2017) Childlessness in Europe: contexts, causes, and consequences. Springer, Switzerland

Kodate N, Tinomen V (2017) Bringing the family in through the back door: the stealthy expansion of family care in Asian and European long-term care policy. J Cross Cult Gerontol 32:291-301. https://doi.org/10.1007/s10823-017-9325-5

Kossek E, Lautsch B (2018) Work-life flexibility for whom? Occupational status and work-life inequality in upper, middle and lower level jobs. Acad Manag Ann 12(1):5-36. https://doi.org/10.5465/ annals.2016.0059

Lain D, van der Horst M, Vickerstaff S (2020) Extended working lives: feasible and desirable for all? In: Czaja S, Sharit J, James J (eds) Current and emerging trends in aging and work. Springer, Switzerland, pp 101-119

Landes S, Settersten R (2019) The inseparability of human agency and linked lives. Adv Life Course Res. https://doi.org/10.1016/j.alcr. 2019.100306

Larsson D, Stattin M (2015) The labour market in ageing Sweden: lifecourse influences on workforce participation. In: Komp K, Johansson S (eds) Population ageing from a lifecourse perspective: critical and international approaches. Policy Press, Bristol, pp 203-220

León M, Pavolini E (2014) 'Social investment' or back to 'familism': the impact of the economic crisis on family and care policies in Italy and Spain. South Eur Soc Polit 19(3):353-369. https://doi. org/10.1080/13608746.2014.948603

Lestari MD, Stephens C, Morison T (2021) Constructions of older people's identities in Indonesian regional ageing policies: The impacts on micro and macro experiences of ageing. Ageing Soc 1-21. https://doi.org/10.1017/S0144686X20001907

Li J, Zehr S (2020) The wellbeing of communities, large and small: a ponderance of HRD. Hum Resour Dev Int 23(2):103-107. https://doi.org/10.1080/13678868.2020.1726604

Liukkonen V, Virtanen P, Vahtera J, Suominen S, Sillanmäki L, Koskenvuo M (2009) Employment trajectories and changes in sense of coherence. Eur J Public Health 20(3):293-298. https:// doi.org/10.1093/eurpub/ckp171

Maes M, Thielemans G, Tretyakova E (2020) Does divorce penalize elderly fathers in receiving help from their children? Evidence 
from Russia. In: Mortelmans D (ed) Divorce in Europe New Insights in trends, causes and consequences of relation breakups. Springer, Switzerland, pp 167-182

Ministerio de Salud (2021). Plan nacional de salud integral para personas mayores y su plan de acción 2020-2030. Resolucion Exenta $\mathrm{N}^{\circ} 499$ del 31 de mayo del 2021. https://diprece.minsal. cl/wp-content/uploads/2021/09/Plan-Nacional-de-Salud-Integ ral-para-Personas-Mayores_v2.pdf Accessed 26 November 2021

Makore BCN, Al-Maiyah S (2021) Moving from the margins: towards an inclusive urban representation of older people in Zimbabwe's policy discourse. Societies 11(1):1-21. https://doi. org/10.3390/soc11010007

Marotz-Baden R, Adams G, Munro B, Munro G (1979) Family form or family process? Reconsidering the deficit family model approach. Fam Coord 28(1):5-14. https://doi.org/10.2307/ 583262

Marques S, Mariano J, Mendonça J, De Tavernier W, Hess M, Naegele L, Peixeiro F, Martins D (2020) Determinants of ageism against older adults: a systematic review. Int J Environ Res Public Health 17(7):1-27. https://doi.org/10.3390/ijerph17072560

McCrillis E, Skinner MW, Colibaba A (2021) Developing rural insights for building age-friendly communities. J Rural Stud 81:336-344. https://doi.org/10.1016/j.jrurstud.2020.10.053

McDonough P, Worts D, Corna L, McMunn A, Sacker A (2017) Laterlife employment trajectories and health. Adv Life Course Res 34:22-33. https://doi.org/10.1016/j.alcr.2017.09.002

McGregor JA (2007) Researching human wellbeing: from concepts to methodology. In: Gough I, McGregor JA (eds) Wellbeing in developing countries: from theory to research. Cambridge University Press, Cambridge, pp 316-350

Michel JP, Leonardi M, Martin M, Prina M (2021) WHO's report for the decade of healthy ageing 2021-30 sets the stage for globally comparable data on healthy ageing. Lancet 2(3):E121-E122. https://doi.org/10.1016/S2666-7568(21)00002-7

Mitra A (2015) Informal economy in India: persistence and meagreness. Agrarian South: J Polit Econ 4(2):216-231

Mokomane Z (2021) Balancing care and work roles among women working in the informal sector in South Africa. Int J Care Caring 5(1):129-147. https://doi.org/10.1332/239788220X15984 634358661

Molendijk T (2018) Toward an interdisciplinary conceptualization of moral injury: from unequivocal guilt and anger to moral conflict and disorientation. New Ideas Psychol 51:1-8

Moyano-Díaz E, Mendoza-Llanos R, Paez-Rovira D (2021) Psychological well-being and its relationship with references and sources of happiness in Chile. J Psychol 39(1):162-182

Mucchi-Faina A, Pacilli MG, Verma J (2010) The two faces of familism: a cross-cultural research in India and Italy. Psychol Stud 55:365-373. https://doi.org/10.1007/s12646-010-0042-1

Muers S (2018) Culture, values and public policy. Institute for Policy Research, University of Bath. https://www.bath.ac.uk/publicatio ns/culture-values-and-public-policy/attachments/ipr-culture-values-and-public-policy.pdf. Accessed 2 July 2021.

Ng ST, Tey NP, Asadullah MN (2017) What matters for life satisfaction among the oldest old? Evidence from China. Plos One 12(2):e0171799. https://doi.org/10.1371/journal.pone.0171799

Ní Léime Á, Street D (2019) Working later in the USA and Ireland: implications for precariously and securely employed women. Ageing Soc 39(10):2194-2218. https://doi.org/10.1017/S0144 686X18000508

Nicholas L, Done N, Baum M (2020) Lifetime job demands and later life disability. J Econ Ag 17:100184. https://doi.org/10.1016/j. jeoa.2018.12.003

Nussbaum M (2002) Capabilities and social justice. Int Stud Rev 4(2):123-135. https://doi.org/10.1111/1521-9488.00258
Obadia L (2015) Spatial turn, beyond geography: a new agenda for sciences of religion? Int Rev Sociol 25(2):200-217. https://doi. org/10.1080/03906701.2015.1039269

Pan American Health Organization (2021) Building health throughout the life course: concepts, implications and application in public health. https://iris.paho.org/bitstream/handle/10665.2/ 53409/9789275123027_eng.pdf?sequence $=1 \&$ isAllowed=y Accessed 2 July 2021.

Perelli-Harris B, Lyons-Amos M (2015) Changes in partnership patterns across the life course: an examination of 14 countries in Europe and the United States. Demogr Res 33:145-178

Polletta F (2018) The multiple meanings of familialism. Law Soc Inq 43(1):230-237. https://doi.org/10.1111/lsi.12340

Radó M, Boissonneault M (2020) Short and long-term change in subjective well-being among voluntary and involuntary retirees. J Econ Ag 17:100178. https://doi.org/10.1016/j.jeoa.2018. 11.003

Raymo JM, Warren JR, Sweeney MM, Hauser RM, Ho JH (2011) Precarious employment, bad jobs, labor unions, and early retirement. J Gerontol Ser B Psychol Sci Soc Sci 66(2):249-259

Rémillard-Boilard S, Buffel T, Phillipson C (2021) Developing agefriendly cities and communities: eleven case studies from around the world. Int J Environ Res Public Health 18(1):133. https://doi. org/10.3390/ijerph18010133

Rogers R (1964) Toward a theory of family development. J Marriage Fam 26(3):262-270. https://doi.org/10.2307/349456

Rondi E, De Massis A, Kotlar J (2019) Unlocking innovation potential: a typology of family business innovation postures and the critical role of the family system. J Fam Bus Strat 10(4):100236. https:// doi.org/10.1016/j.jfbs.2017.12.001

Roux A, Viljoen D (2018) Using futures studies methodologies to explore the economic participation of the older cohorts of South Africa's population towards 2030. J Futures Stud 23(1):5-22. https://doi.org/10.6531/JFS.201809_23(1).0002

Ryser L, Halseth G, Markey S, Hanlon N, Skinner M (2021). In: Skinner M, Winterton R, Walsh K (eds) Rural gerontology: towards critical perspectives on rural ageing. Routledge, London, pp $152-163$

Saraceno C (2016) Varieties of familialism: comparing four southern European and East Asian welfare regimes. J Eur Soc Policy 26(4):314-326

Schmitz A (2021) Gendered experiences of widowhood and depression across Europe: the role of loneliness and financial resources from a longitudinal perspective. J Affect Disord 280:114-120. https:// doi.org/10.1016/j.jad.2020.11.091

Sen A (1999) Commodities and capabilities. Oxford University Press, Oxford

Siegmann K, Schiphorst F (2016) Understanding the globalizing precariat: From informal sector to precarious work. Progr Dev Stud 16(2):111-123

Silverstein M, Giarrusso R (2010) Aging and family life: a decade review. J Marriage Fam 72:1039-1058. https://doi.org/10.1111/j. 1741-3737.2010.00749.x

Sis SS, Safaeeian A, Zeinalhajlou AA, Matlabi H (2020) Viewpoints of older people toward the features of age-friendly communities: map for charting progress in Tabriz, Iran. J Ag Environ https:// doi.org/10.1080/26892618.2020.1859037

Skinner M, Alun J, Hanlon N, Halseth G, Ryser L (2016) Voluntarism, older people, and ageing places: pathways of integration and marginalization. In: Skinner M, Hanlon N (eds) Ageing resource communities: new frontiers of rural population change, community development and volunteerism. Routledge, London, pp 38-54

Smith D (1993) The standard North American family: SNAF as an ideological code. J Fam Issues 14(1):50-65. https://doi.org/10. 1177/0192513X93014001005 
Stephens C, Szabó Á, Allen J, Alpass F (2019) Livable environments and the quality of life of older people: an ecological perspective. Gerontologist 59(4):675-685. https://doi.org/10.1093/geront/ gny043

Stoilova M, Roseneil S, Carter J, Duncan S, Phillips M (2017) Constructions, reconstructions and deconstructions of 'family' amongst people who live apart together (LATs). Br J Sociol 68(1):78-96. https://doi.org/10.1111/1468-4446.12220

The Ministry of Justice and Human Rights the Republic of Indonesia (2021) Regulation of the President of the Republic of Indonesia, No. 88 year 2021 about National Strategic Plan on Ageing. Available at https://jdih.bappenas.go.id/peraturan/detailperaturan/2700

The WHOQOL Group (1998) The World Health Organization quality of life assessment (WHOQOL): development and general psychometric properties. Soc Sci Med 46(12):1569-1585. https:// doi.org/10.1016/S0277-9536(98)00009-4

Ting GHY, Woo JD (2009) Elder care: is legislation of family responsibility the solution? Asian J Gerontol Geriatr 4(2):72-75

Tronto J (2017) There is an alternative: homines curans and the limits of neoliberalism. Int J Care Caring 1(1):27-43. https://doi.org/ $10.1332 / 239788217 X 14866281687583$

Tseng YC, Liu SHY, Lou MF, Huang GS (2018) Quality of life in older adults with sensory impairments: a systematic review. Qual Life Res 27:1957-1971. https://doi.org/10.1007/s11136-018-1799-2

UN Sustainable Development Goals (2015) Transforming our world: the 2030 agenda for sustainable development. United Nations. https://sustainabledevelopment.un.org/post2015/transformingour world/publication Accessed 25 June 2021

United Nations (2021) Leaving no one behind. https://www.un.org/fr/ desa/leaving-no-one-behind Accessed 2 July 2021.

Urbaniak A, Walsh K (2019) The interrelationship between place and critical life transitions in later life social exclusion: a scoping review. Health Place 60:102234. https://doi.org/10.1016/j.healt hplace.2019.102234

van Exel NJA, Brouwer WBF, van den Berg B, Koopmanschap MA, van den Bos GAM (2004) What really matters: an inquiry into the relative importance of dimensions of informal caregiver burden. Clin Rehabil 18(6):683-693. https://doi.org/10.1191/02692 $15504 \mathrm{cr} 743 \mathrm{oa}$

Van Winkle Z (2018) Family trajectories across time and space: increasing complexity in family life courses in Europe? Demography 55:135-164. https://doi.org/10.1007/s13524-017-0628-5

Van Winkle Z, Fasang A (2017) Complexity in employment life courses in Europe in the twentieth century-large cross-national differences but little change across birth cohorts. Soc Forces 96(1):1-30. https://doi.org/10.1093/sf/sox032

Velarde-Jurado E, Avila-Figueroa C (2002) Methodological considerations for evaluating quality of life. Salud Publica Mex 44(5):448-463

Vervaecke D, Meisner B (2021) Caremongering and assumptions of need: the spread of compassionate ageism during COVID-19. Gerontologist 61(2):159-165. https://doi.org/10.1093/geront/ gnaa131

Visser M, Gesthuizen M, Kraaykamp G, Wolbers M (2018) Labor market vulnerability of older workers in the Netherlands and its impact on downward mobility and reduction of working hours. Work, Ag Retire 4(3):289-299. https://doi.org/10.1093/workar/ wax017

Vos WH, van Boekel LC, Janssen MM, Leenders RTAJ, Luijkx KG (2020) Exploring the impact of social network change: experiences of older adults ageing in place. Health Soc Care Commun 28(1):116-126. https://doi.org/10.1111/hsc.12846

Wahl HW, Oswald F (2016) Theories of environmental gerontology: old and new avenues for person-environmental views of aging. In: Bengsten V, Settersten R (eds) Handbook of theories of ageing, 3rd edn. Springer, Switzerland, pp 621-641

Walsh K, Scharf T, Keating N (2017) Social exclusion of older persons: a scoping review and conceptual framework. Eur J Ageing 14:81-98. https://doi.org/10.1007/s10433-016-0398-8

Walsh K, O'Shea E, Scharf T (2020) Rural old-age social exclusion: a conceptual framework on mediators of exclusion across the lifecourse. Ageing Soc 40(11):2311-2337. https://doi.org/10.1017/ S0144686X19000606

Walsh K, Scharf T, Van Regenmortel S, Wanka A (eds) (2021) Social exclusion in later life: interdisciplinary and policy perspectives. Springer, Switzerland

Webb C (2021) Liberating the family: debt, education and racial capitalism in South Africa. Soc Space 39(1):85-102

Widmer ED, Girardin M, Ludwig C (2018) Conflict structures in family networks of older adults and their relationship with health-related quality of life. J Fam Issues 39(6):1573-1597

Wiles JL, Rolleston A, Pillai A, Broad J, Teh R, Gott M, Kerse N (2017) Attachment to place in advanced age: a study of the LiLACS NZ cohort. Soc Sci Med 185:27-37. https://doi.org/10. 1016/j.socscimed.2017.05.006

Winterton R (2016) Organizational responsibility for age-friendly social participation: views of Australian rural community stakeholders. J Aging Soc Policy 28(4):261-276. https://doi.org/10. 1080/08959420.2016.1145504

Wiseman J, Brasher K (2008) Community wellbeing in an unwell world: trends, challenges, and possibilities. J Public Health Pol 29:353-366. https://doi.org/10.1057/jphp.2008.I6

World Health Organization (2015) World report on ageing and health. https://apps.who.int/iris/handle/10665/186463 Accessed 2 July 2021

World Health Organization (2020) UN Decade of Healthy Ageing: plan of action. https://www.who.int/initiatives/decade-of-healt hy-ageing Accessed 25 June 2021

World Health Organization (2021) Decade of healthy ageing: baseline report. https://www.who.int/publications/i/item/9789240017900 Accessed 25 June 2021

WHO Global Report on Ageism (2021) Global report on ageism. Geneva: World Health Organization; 2021. Licence: CC BYNC-SA 3.0 IGO

Publisher's Note Springer Nature remains neutral with regard to jurisdictional claims in published maps and institutional affiliations. 